\title{
Atypical distyly in Psychotria goyazensis Mull. Arg. (Rubiaceae), an intramorph self-compatible species
}

Ebenezer Barbosa Rodrigues ${ }^{1}$ and Hélder Consolaro ${ }^{2,3}$

Submitted: 21 August, 2012. Accepted: 15 November, 2012

\begin{abstract}
Distyly is a genetically controlled floral dimorphism, characterized by the reciprocal positioning of pin and thrum morphs, a heteromorphic incompatibility system and a balanced morph ratio (isoplethy). This study aimed to investigate the phenology, features of distyly, reproductive biology, and floral visitors of Psychotria goyazensis Mull. Arg. (Rubiaceae), an intramorph self-compatible species, in a tropical semideciduous forest in the municipality of Catalão, located in the state of Goiás, Brazil. The phenology was recorded for a sample of individuals, the floral morphology being described using fresh and fixed material. The incompatibility system was tested using controlled hand pollinations. Floral visitors were collected and identified. Blooming began in November 2009 and ended in April 2010. Fruits developed from December 2009 to March 2010. The population presented atypical distyly, because only plants with pin flowers were found. The intramorph and open pollinations set more fruits than did spontaneous self-pollinations. The main flower visitors were Systropus sp. (Diptera), as well as Hymenoptera and Lepidoptera species. Morphological variations in distyly can occur by breakdown/permutation of the gene that controls the polymorphism. However, some authors argue that, in Rubiaceae, genetic control of the incompatibility system can operate independently of the morphological factor, and species might respond in different ways to the same selective pressures.
\end{abstract}

Key words: heterostyly, monomorphism, cerrado, reproductive biology

\section{Introduction}

Heterostyly is genetically controlled floral polymorphism, characterized by reciprocal positioning of stigmas and anthers between morphs (reciprocal herkogamy), as well as by an intramorph self-incompatibility system (Ganders 1979). The most common manifestation of heterostyly is distyly, in which the two floral morphs, pin flowers (stigma above the anthers) and thrum flowers (stigma below the anthers), occur separately (Hamilton 1990). These morphs are usually found in similar proportions within populations (isoplethy); these features are controlled by genetic and ecological mechanisms, such as the incompatibility system and intermorph pollen transfer (Ganders 1979).

In some botanical families, the incompatibility system and floral morphs are controlled by a single genetic component, usually referred to as a supergene, whereby the thrum morph presents the heterozygous genotype and the pin morph presents the recessive homozygous genotype (Barrett 1990). However, some authors argue that, in certain families (especially Rubiaceae), the morphological and physiological integrity of the supergene differs from that seen in other families (Richards 1986; Lewis \& Jones 1992; Barrett \& Shore 2008; Consolaro et al. 2011). Some Rubiaceae genera, such as Psychotria, Palicourea, Coccocypselum, Declieuxia, Sabicea, Guettarda and Manettia, are known to be typically distylous but present anomalies or breakdown of distyly (Sobrevila et al. 1983; Hamilton 1990; Richards \& Koptur 1993; Passos \& Sazima 1995; Faivre \& McDade 2001, Coelho \& Barbosa 2003; Consolaro et al. 2009).

It is estimated that in Brazilian savanna (cerrado), distylous species represent approximately $41 \%$ of the Rubiaceae taxa (H. Consolaro, personal observation). In the Psychotrieae tribe, distyly seems to be a primitive feature and is taxonomically widespread, other reproductive systems in the tribe therefore being attributed to some evolutionary variation of distyly (Hamilton 1990). Because of different evolutionary and ecological implications, disturbance in the plant-pollinator relationship and genetic changes in the distyly, the floral structures and the frequency of the

\footnotetext{
${ }^{1}$ Universidade Federal de Uberlândia, Programa de Pós Graduação em Ecologia e Conservação de Recursos Naturais, Laboratório de Morfologia Microscopia e Imagem, Uberlândia, MG, Brazil

${ }^{2}$ Universidade Federal de Goiás, Departamento de Ciências Biológicas, Laboratório Integrado de Zoologia e Botânica, Catalão, GO, Brazil

${ }^{3}$ Author for correspondence: helderconsolaro@gmail.com
} 
morphs can vary, resulting in the loss of one of the morphs (monomorphism) or a rearrangement of the reproductive structures, which can be placed at the same height (homostyly, Ganders 1979).

Plants show many different phenological strategies to avoid overlap between blooming and fruiting, as well as to compete for pollinators and seed dispersers, given that these adaptations can improve the fitness and survival of these species (Monasterio \& Sarmiento, 1976; Bullock 1985). In recent decades, the number of studies on heterostyly and phenology of heterostylous species in the cerrado has been increasing (Monteiro et al. 1991; Coelho \& Barbosa 2003; Coelho \& Barbosa 2004; Consolaro et al. 2005; Toledo et al. 2007; Lenza et al. 2008; Oliveira 2008; Consolaro et al. 2009; Machado et al. 2010; Consolaro et al. 2011) and could be compared to those conducted in the Atlantic Forest (Passos \& Sazima 1995; Lopes \& Buzato 2005; Castro \& Oliveira 2002; Castro et al. 2004; Teixeira \& Machado 2004a, 2004b; Rossi et al. 2005; Pereira et al. 2006; Mendonça \& Anjos 2006; Virillo et al. 2007, Fonseca et al. 2008). To increase understanding of the heterostyly system in the cerrado, this study aimed to investigate the phenology, distylous features, reproductive biology and floral visitors of Psychotria goyazensis Mull. Arg. (Rubiaceae).

\section{Material and methods}

\section{Study site}

The study was carried out from April 2009 to April 2010 in a forest fragment of approximately 26 ha in the municipality of Catalão, located in the state of Goiás, Brazil (18 ${ }^{\circ}$ '36.595"S; $\left.47^{\circ} 55^{\prime} 33,989^{\prime \prime} \mathrm{W}\right)$. According to the Köppen classification system (Köppen 1958), the climate of the study area is type Aw, with a dry season from May to September and a rainy season from October to April.

\section{Phenology}

We marked 45 plants, with at least $5 \mathrm{~m}$ between individuals. During the reproductive phase (flowering and fruiting), observations were made on a weekly basis, whereas they were made once every two weeks during the vegetative phase. The development of flower buds, the appearance of open flowers (blossoming) and fruiting were recorded. To evaluate the phenological phases, we employed the activity and intensity indices devised by Bencke \& Morellato (2002). The activity index analyzes the presence or absence of each phenological phase (flower buds, flowers and fruits), evaluating the synchrony of the phenological events among the plants. The intensity index uses the classes established by Fournier (1974), showing the peak intensity of each phenological event on a five-point scale: $0=0 \% ; 1=25 \% ; 2=50 \% ; 3=75 \%$; and $4=100 \%$. Phenological patterns were classified using the categories described by Newstron et al. (1994).

\section{Floral biology}

Forty pre-anthesis buds were marked on 10 random plants ( 4 buds per plant). The floral longevity, the release of pollen by the anthers and the beginning of anthesis were recorded. Anthesis onset was defined as the beginning of the opening of corolla lobes, and the end of floral longevity was defined as a loss of brightness and a change in the color of the corolla. The release of pollen was determined by observation of loose pollen on the anthers. Stigma receptivity was determined by the separation of the stigma lobes $(n=16)$, which is usually suitable for studies of Rubiaceae (Coelho \& Barbosa 2003, Consolaro et al. 2005, Consolaro et al. 2009, Consolaro et al. 2011).

\section{Distyly and incompatibility system}

Five flowers per individual were collected from 20 plants. The lengths of the corolla tube, stamens, pistil and stigma lobes were measured under a stereomicroscope and are expressed as mean \pm standard error of mean. The fruit set resulting from controlled hand pollination was used in order to determine the incompatibility system. In 27 plants, flower buds in pre-anthesis $(n=172)$ were isolated and bagged. When the flower buds opened, the following treatments were applied: self-pollination (exposure to pollen from the same flower, $n=41$ ); intramorph cross-pollination (exposure to pollen from flowers of different plants of the same morph, $n=42$ ); spontaneous self-pollination (flowers tagged and bagged, $\mathrm{n}=48$ ); and control (flowers marked and exposed to open pollination, $\mathrm{n}=41$ ). We did not expose flowers to intermorph cross-pollination, because the studied population was strictly monomorphic. The index of self-incompatibility (ISI) was calculated as the ratio between the proportion of fruit production by selfing and that resulting from intramorph cross-pollinations. An ISI greater than 0.25 was considered indicative of self-compatibility (adapted from Bullock 1985).

\section{Floral visitors}

During four days at the blooming season, we observed the flower visitors of 14 plants. Observations were intercalated at the morning and at the afternoon (from 06:00h to 16:00h), with four hours of duration and a total of $24 \mathrm{~h}$ of observation. The floral visitors were categorized as nectar robbers (those "robbing" nectar from outside the corolla, i.e., without making contact with the anthers or stigma) or pollinators (those taking nectar or pollen and making contact with the anthers and stigma). The frequency and type of approach to the flowers were also recorded, and the visitors were collected and identified. The reproductive efficiency index was calculated as the ratio between the control (open pollination) fruit set and the intramorph cross-pollination fruit set (adapted from Ruiz \& Arroyo 1978). 


\section{Statistical analysis}

A two-tailed $t$-test was used in order to identify differences between the anthers and stigma heights, and a chi-square test was applied in order to compare the fruit-set frequency between the hand pollinations treatments. Data analysis was performed using BioEstat 3.0 software (Ayres et al. 2003).

\section{Results}

\section{Phenology}

The reproductive phenology of P. goyazensis showed an annual intermediate pattern (sensu Newstron et al. 1994): it presented only one flowering cycle over a year with an approximate duration of four months (Fig. 1). Buds began to appear in November and continued to appear until the end of February, and flowering began at the end of November 2009 and continued until April 2010, both phenological phases occurring during the rainy season. During the flowering peak, we noted that the proportion of plants with open flowers in the population (25.58\%) was substantially lower than the observed proportion of plants showing floral buds (73.78\%). As can be seen in Fig. 1, fruit production occurred concurrently with flowering, beginning in December 2009, the fruits maturing in March 2010 (at the beginning of the dry season). At all stages observed, the synchrony between individuals was approximately $41.33 \%$, although the proportion of plants with evidence of phenological phases ranged from $11.71 \%$ to $100 \%$.

\section{Floral biology}

Psychotria goyazensis has white tetramerous or pentamerous flowers (Fig. 2), arranged in cymose inflorescences. They lasted approximately $12 \mathrm{~h}$, presenting nectar and pollen as floral resources. Inside the corolla, there is a ring of trichomes arranged in the middle portion of the tube, above which are the four stamens. Anthesis began at $05: 00 \mathrm{~h}$ flowers typically being fully opened by $06: 00 \mathrm{~h}$, at which time stigmas became receptive and pollen release began.

\section{Distyly and isoplethy}

Psychotria goyazensis presented a case of atypical distyly, because only the pin morph was found in the population (pin monomorphism). The pin morph flowers had a mean corolla tube length of approximately $3.1 \pm 0.33$ $\mathrm{mm}$, mean stamen height of $2.77 \pm 0.02 \mathrm{~mm}$, mean pistil height of $3.27 \pm 0.03 \mathrm{~mm}$ and mean stigma lobe length of $1.9 \pm 0.32 \mathrm{~mm}$. The difference among the heights of the reproductive structures was significant $\left(\mathrm{t}_{2,93}=16.48, p<0.01\right)$, characterizing the pin morph. The mean anther-stigma separation was $0.5 \pm 0.03 \mathrm{~mm}$, with an apparent variation in herkogamy between flowers. A few flowers presented pistils at approximately the same level as or even slightly below the anthers (Fig. 3).

\section{Incompatibility system}

Psychotria goyazensis showed intramorph and self-compatibility, with an index of self-incompatibility of 0.96 . As can be seen in Tab. 1, there was no significant difference between self-pollination and intramorph cross-pollination in terms of fruit set $\left(\chi^{2}=0.017, p>0.05\right)$. We also found that the fruit set resulting from spontaneous self-pollination did not differ significantly from that resulting from the cross-pollination and open pollination (control) treatments (reproductive efficiency index $=1.19, \chi^{2}=0.38, p=0.61$ ). Fruit set was observed 15 to 20 days after controlled hand pollinations.

\section{Floral visitors}

Only insects were observed visiting the flowers of $P$. goyazensis. Most of the visits $(52 \%, \mathrm{n}=60)$ were made by Diptera (Systropus sp., mimics of Hymenoptera, $43 \%$ of the visits being made by flies of the Conopidae and Syrphidae families), bees (Halictidae, 2 species), wasps (Polistinae, 2 species), and butterflies (Nymphalidae and Danainae). The visits were legitimately performed, meaning that the visitors apparently touched the anthers and stigmas with the front of their body and were primarily seeking nectar. We identified no nectar robbers. Although visits were recorded throughout the day, they were more frequent at times when there was a higher incidence of sunlight on plants (between 9:00h and 11:00h). Pollinators visited many flowers on the same plant and flowers on plants that were closer to each other.

\section{Discussion}

The blooming pattern of Rubiaceae and Psychotria species in the cerrado often seems to be linked to the rainy season in this ecosystem (Martin-Gajardo \& Morellato 2003, Lopez \& Buzato 2005, Consolaro et al. 2011). However, the bloom period and the fructification of many species can result not only from abiotic selective pressures, such as the climate system, but also as a way to enhance survival strategies when the species will be able to disperse and germinate its seeds (Sarmiento \& Monasterio 1983). The synchrony among the studied plants followed the intensity of occurrence of the phenological phases observed, a pattern found in other Psychotria species (Augspurger 1983; Coelho \& Barbosa 2004). The timing of a phenological phase, such as flowering and fruiting, is closely related to endogenous factors and abiotic factors that influence the physiology of plants (Bencke \& Morellato 2002). Nevertheless, in an ecological context, this fact is important because it contributes to the reproductive process of the species, increasing the 


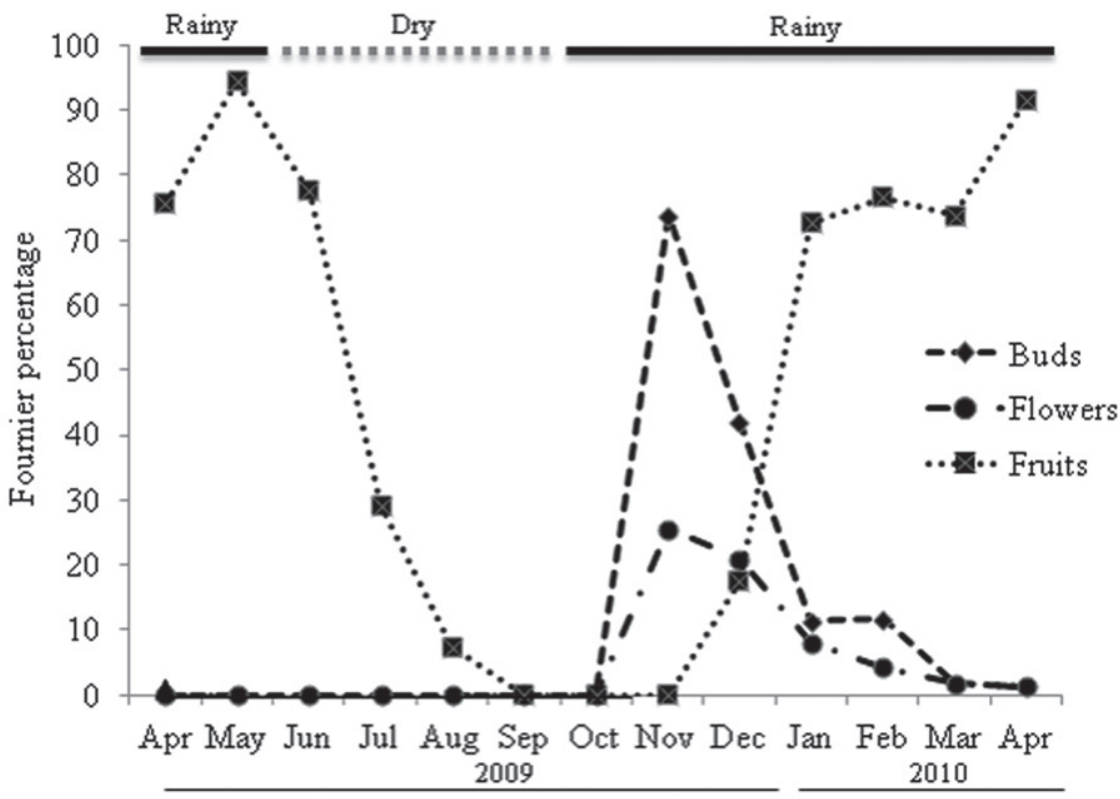

Figure 1. Phenology as proportional intensity for each phenophase (budding, flowering and fruit production) of Psychotria goyazensis Mull. Arg. in a forest fragment in the municipality of Catalão, state of Goiás, Brazil.

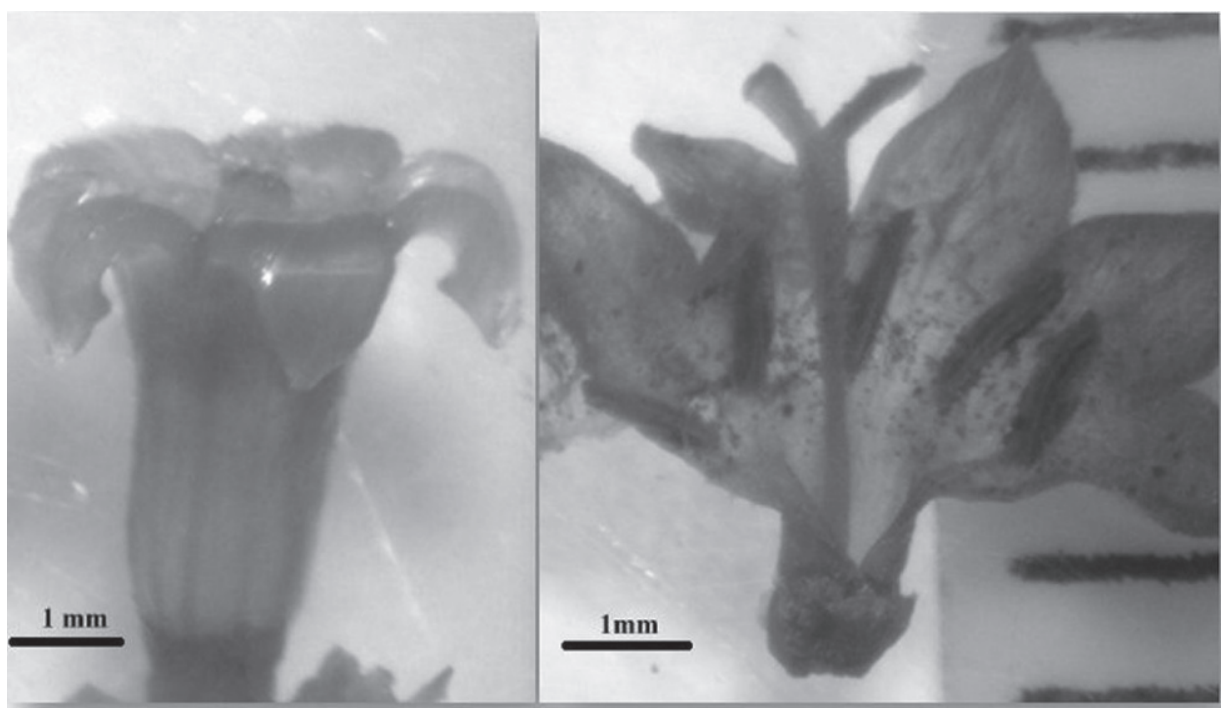

Figure 2. Psychotria goyazensis Mull. Arg. flowers. A: Corolla of pin flower. B: Reproductive structures of pin flower in a forest fragment in the municipality of Catalão, state of Goiás, Brazil.

power of attraction and the maintenance of pollinators and seed dispersers in the habitat.

In the study area, we recorded five other Psychotria species that bloom simultaneously with $P$. goyazensis, to which they are also similar in terms of morphology and floral biology: P. deflexa, P. prunifolia, P. hoffmannseggiana, P. trichophoroides and P. capitata (H. Consolaro, personal observation). The coexistence of plants whose flowering times overlap could have a facilitating effect on pollination, increasing the attraction of pollinators to neighboring spe- cies (Feldman et al. 2004). However, it can also expose these species to interspecific competition for pollinators, having a negative impact on pollen transfer and fruit production (Pleasants 1980).

Because the number of studies on the reproductive biology of Psychotria species is increasing, it is often possible to find the occurrence of monomorphic populations, especially pin species (Ganders 1979, Sakai \& Wright 2008; Consolaro et al. 2011). The same pin monomorphism found in $P$. goyazensis has been also reported in $P$. carthagenensis (Con- 


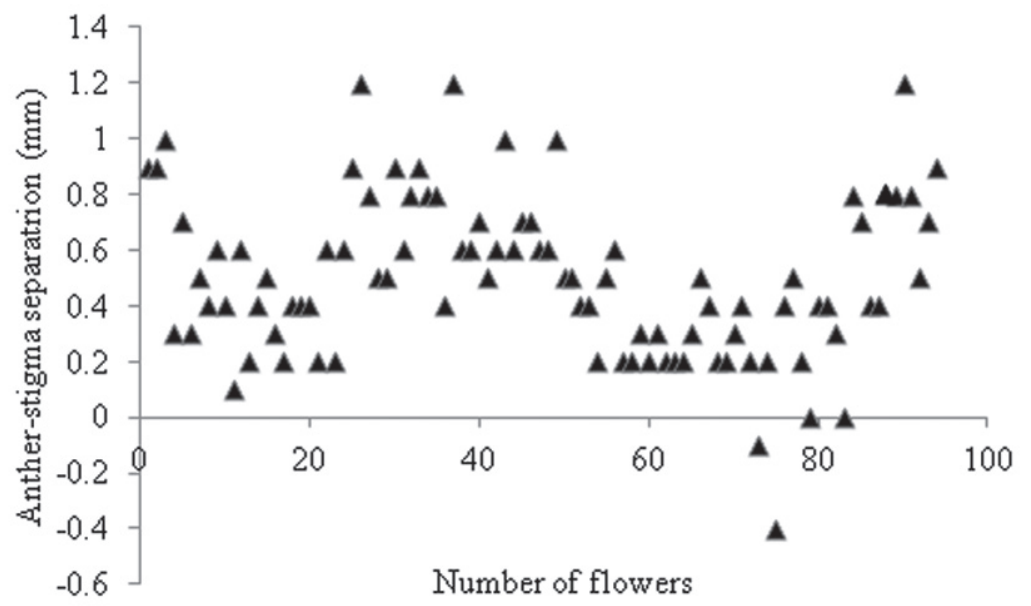

Figure 3. Anther-stigma separation of Psychotria goyazensis Mull. Arg. flowers in a forest fragment in the municipality of Catalão, state of Goiás, Brazil.

solaro et al. 2011) and P. graciliflora, P. hoffmannseggiana, P. micrantha and P. tenuifolia (Sakai Wright \& 2008). Four of the five Psychotria species in the study area are typically distylous (P. hoffmannseggiana, $P$. capitata, $P$. deflexa and $P$. trichophoroides), although $P$. prunifolia is also pin monomorphic (E. Rodrigues, personal observation). A recent phylogenetic analysis showed that such unbalanced morph ratios can arise independently (Sakai \& Wright 2008). Such ratios can also be observed among populations of the same species (Koch et al. 2010; Consolaro et al. 2011; Farias et al. 2012), as well as in congeneric species (Consolaro et al. 2009), although other species are relatively stable (e.g. Machado et al. 2010). In P. goyazensis, we were unable to determine how widespread pin monomorphism is among its populations.

There is no concrete information about how the genetic control of distyly in Rubiaceae works, but studies of other families indicate that a diallelic system organized as a supergene controls the morphological and incompatibility features of distyly (Richards 1986; Lewis \& Jones 1992; Barrett \& Shore 2008). When a breakdown of distyly occurs by a recombination in the supergene (Lewis \& Jones 1992), the most common result would be the formation of homostylous self-compatible flowers, with reproductive structures at the same height (Ganders 1979; Consolaro et al. 2009). The breakdown of distyly can also be correlated with the ploidy level in some Rubiaceae species (Naiki \&Nagamasu 2004; Naiki 2012). However, it is known that a gain in compatibility can occur without rearrangement of the reproductive structures (Sobrevila et al. 1983; Barrett 1988; Consolaro et al. 2011), which indicates that the action of the supergene in Rubiaceae is not very clear. The occurrence of pin monomorphism and self-compatibility in the studied population of $P$. goyazensis, as shown in $P$. carthagenensis (Consolaro et al. 2011), supports the idea that in Rubiaceae the control of the incompatibility system could act independently of the morphological factor.
The development of an autogamous reproductive mechanism becomes advantageous when pollination service and compatible pollen transfer is lost and seed production is deficient (Schoen et al. 1996). Distylous species rely on an accurate intermorph pollen transfer due to the incompatibility system, so that the loss or laxity of this system becomes advantageous in case of disturbance of the plant-pollination relationship (Ganders 1979).

In the present study, P. goyazensis flowers were mainly visited by flies, a rare situation for this genus that has bees as its main pollinators (Bawa \& Beach 1983; Castro \& Oliveira 2002). Variations in the type of pollinator among congeneric species might have a negative impact on intermorph pollen transfer, because the floral architecture might not favor contact with flower visitors (Consolaro et al. 2009), especially Syrphidae, which have a smaller body size and distinct behavior (Proctor et al. 1996). In addition, even when Diptera species visit the flowers, the visits happen during specific periods of the day (between 08:00h and 12:00h), many Syrphidae species having been shown to present such behavior (Weems 1953). With visits of pollinators to $P$. goyazensis flowers restricted to specific times of day, the pollination service could have become limited and insufficient. The irregular frequency of visits and instability in the pollen transfer might have favored the loss of incompatibility in the studied population.

Because there was a comparatively normal fruit set after spontaneous self-pollination treatment, we cannot exclude the possibility of apomixis in this population. However, in tiny flowers, such as those of P. goyazensis, the anther-stigma separation might be insufficient to avoid spontaneous self-pollination. Their size also renders emasculation and agamospermy treatments impractical. Even herkogamy, which results in significant differences in height of the reproductive structures, might not be sufficient to prevent deposition of self-pollen on the pistil. Dai \& Galloway (2011) suggested that there are cases in which herkogamy does not function 
Table 1. Fruit set of controlled hand pollination experiments of Psychotria goyazensis Mull. Arg. (Rubiaceae) flowers from a forest fragment in the municipality of Catalão, state of Goiás, Brazil.

\begin{tabular}{lc}
\hline Treatment (n of flower buds) & $\begin{array}{c}\text { Fruiting } \\
\mathrm{n}(\%)^{*}\end{array}$ \\
\hline Self-pollination $(\mathrm{n}=41)$ & $29(70.73)^{\mathrm{a}}$ \\
Intramorph cross-pollination $(\mathrm{n}=42)$ & $30(71.42)^{\mathrm{a}}$ \\
Spontaneous self-pollination $(\mathrm{n}=48)$ & $19(39.58)^{\mathrm{b}}$ \\
Open-pollination control $(\mathrm{n}=41)$ & $35(85.36)^{\mathrm{a}}$ \\
\hline
\end{tabular}

${ }^{*}$ Different letters indicate a significant difference between values $(\mathrm{p}<0.05)$.

as a system that prevents self-pollination but only a way to increase pollen transfer and outcrossing, which could be the case among flowers of P. goyazensis.

The overlap between $P$. goyazensis and the five other Psychotria species, in terms of blooming time; together with the fact that $P$. goyazensis has small Diptera as its main pollinators and a limited time for pollination as a function of the foraging activity of the floral visitors, as well as having tiny flowers, might have contributed to the occurrence of variations in the reproductive system of the studied population. However, it was not possible to establish pin monomorphism or self-compatibility as features of the studied species, because the anomalies might be restricted to this population. Pin and thrum flowers of P. goyazensis have been described from herbarium material (Delprete 2010), so it is possible that isoplethic and truly distylous populations occur elsewhere. For Rubiaceae, especially in studies of Psychotria, the genetic control of the incompatibility system and the floral morphology by a supergene does not seem to be well-defined. Therefore, further specific studies in this family are needed in order to improve understanding of distyly and its variations in the Rubiaceae family, which presents a larger number of distylous species than does any other family of angiosperms.

\section{References}

Augspurger, C.K. 1983. Offspring recruitment around tropical trees: changes in cohort distance with time. Oikos 40: 189-196.

Ayres, M.; Ayres, D.L. \& Santos, A.S. 2003. BioEstat 3.0: aplicações estatísticas nas áreas das ciências biológicas e médicas. Belém, Sociedade Civil Mamirauá.

Barrett, S.C.H. 1988. Evolution and breeding systems in Eichhornia: a review. Annals of the Missouri Botanical Garden 75: 741-760.

Barrett, S.C.H. 1990. The evolution and adaptive significance of heterostyly. Tree 5: 144-148.

Barrett, S.C.H. \& Shore J.S. 2008. New insights on heterostyly: comparative biology, ecology and genetics. Pp. 3-32. In: Franklin-Tong V.E. (Ed.). Self-Incompatibility in Flowering Plants-Evolution, Diversity and Mechanisms. Berlin, Springer-Verlag.

Bawa, K.S. \& Beach, J.H. 1983. Self-incompatibility systems in the Rubiaceae of a tropical lowland wet forest. American Journal of Botany 70: 1281-1288.
Bencke, C.S.C. \& Morellato, L.P.C. 2002. Comparação de dois métodos de avaliação da fenologia de plantas, sua interpretação e representação. Revista Brasileira de Botânica 25: 269-275.

Bullock, S.H. 1985. Breeding systems in the flora of a tropical deciduous forest. Biotropica 17: 287-301.

Castro, C.C. \& Oliveira, P.E. 2002. Pollination biology of distylous Rubiaceae in the Atlantic Rain Forest, SE Brazil. Plant Biology 4: 640-646.

Castro, C.C.; Oliveira, P.E. \& Alves, M.C. 2004. Breeding system and floral morphometry of distylous Psychotria L. species in the Atlantic Rain Forest, SE Brazil. Plant Biology 6: 755-760.

Coelho, C.P. \& Barbosa, A.A. 2003. Biologia reprodutiva de Palicourea macrobotrys Ruiz \& Pavon (Rubiaceae): um possível caso de homostilia no gênero Palicourea Aubl. Revista Brasileira de Botânica 26: 403413.

Coelho, C.P. \& Barbosa, A.A. 2004. Biologia reprodutiva de Psychotria poeppigiana Mull. Arg. (Rubiaceae) em mata de galeria. Acta Botanica Brasilica 18: 81-489

Consolaro, H.; Silva, E.B. \& Oliveira, P.E. 2005. Variação floral e biologia reprodutiva de Manettia cordifolia Mart. (Rubiaceae). Revista Brasileira de Botânica 28: 85-94.

Consolaro, H.; Toledo, R.D.P.; Ferreguti, R.L.; Hay, J. \& Oliveira, P.E. 2009. Distilia e homostilia em espécies de Palicourea Aubl. (Rubiaceae) do Cerrado do Brasil Central. Revista Brasileira de Botânica 32: 677-689.

Consolaro, H; Silva, S.C.S. \& Oliveira, P.E. 2011. Breakdown of distyly and pin-monomorphism in P. carthagenensis Jacq. (Rubiaceae). Plant Species Biology 26: 24-32.

Dai, C. \& Galloway, L.F. 2011. Do dichogamy and herkogamy reduce sexual interference in a self-incompatible species? Functional Ecology 25: 271-278.

Delprete, P.G. 2010. Flora dos Estados de Goiás e Tocantins: Rubiaceae/ Piero Giuseppe Delprete: Coordenador José Ângelo Rizzo - Goiânia: PRPPG/UFG e IRD. Coleção Rizzo.

Faivre, A.M. \& McDade, L.A. 2001. Population-level variation in the expression of heterostyly in three species of Rubiaceae: does reciprocal placement of anthers and stigmas characterize heterostyly? American Journal of Botany 88: 841-853.

Feldman, T.S; Morris, W.F. \& Wilson, W.G. 2004. When can two plant species facilitate each other's pollination? Oikos 105: 197-207.

Fonseca, L.C.N.; Almeida, E.M. \& Alves, M.A.S. 2008. Fenologia, morfologia floral e visitantes de Psychotria brachypoda (Müll. Arg.) Britton (Rubiaceae) em uma área de Floresta Atlântica, Sudeste do Brasil. Acta Botanica Brasilica 22: 63-69.

Fournier, L.A. 1974. Un método cuantitativo para la medición de características fenológicas en árboles. Turrialba 24: 422-423.

Ganders, F.R. 1979. The biology of heterostyly. New Zealand Journal of Botany 17: 607-635.

Hamilton, C.W. 1990. Variations on a distylous theme in Mesoamerican Psychotria subgenus Psychotria (Rubiaceae). Memoirs of the New York Botanical Garden 55: 65-75.

Koch, A.K.; Silva, P.C. \& Silva, C.A. 2010. Biologia Reprodutiva de Psychotria carthagenensis Jacq. (Rubiaceae), espécie distílica de fragmento floresta de mata ciliar, Centro Oeste do Brasil. Rodriguésia 61: 551-558.

Köppen, W.; Geiger, R. 1928. Klimate der Erde. Gotha: Verlag Justus Perthes. Wall-map $150 \mathrm{~cm} \times 200 \mathrm{~cm}$.

Lenza, E.; Ferreira J.N.; Consolaro H. \& Aquino F.G. 2008. Biologia reprodutiva de Rourea induta Planch. (Connaraceae), uma espécie heterostílica de cerrado do Brasil Central. Revista Brasileira de Botânica 31: 389-398.

Lewis, D. \& Jones D.A. 1992. The genetics of heterostyly. Pp 129-150. In: Barrett, S.C.H. (Ed.). Evolution and Function of Heterostyly. New York, Springer-Verlag.

Lopes, L.E. \& Buzato, S. 2005. Biologia reprodutiva de Psychotria suterella Muell. Arg.(Rubiaceae) e a abordagem de escalas ecológicas para a fenologia de floração e frutificação. Revista Brasileira de Botânica 28: 785-795.

Machado, A.O.; Silva, A.P.; Consolaro, H.; Barros, M.A.G. \& Oliveira, P.E. 2010 Breeding biology and distyly in Palicourea rigida H.B. \& K. (Rubiaceae) in the Cerrado of Central Brazil. Acta Botanica Brasilica 24(3): 686-696. 
Martin-Gajardo, I.S. \& Morellato, P.C. 2003. Fenologia de Rubiaceae do sub-bosque em floresta Atlântica no sudeste do Brasil. Revista Brasileira de Botânica 26: 299-309.

Mendonça, L.B. \& Anjos, L. 2006. Flower morphology, nectar features, and hummingbird visitation to Palicourea crocea (Rubiaceae) in the Upper Paraná River floodplain, Brazil. Anais da Academia Brasileira de Ciências 78: 45-57.

Monasterio, M.; Sarmiento, G. 1976. Phenological strategies of plants species in the tropical savanna Venezuelan Llanos. Journal of Biogeography 3: $325-356$.

Monteiro, R.; Nakajima, J.N.N; Ribeiro, J.E.L.S. \& Toledo, J.C. 1991. Morfologia e distribuição espacial das formas heterostílicas de Psychotria barbiflora DC. (Rubiaceae). Naturalia 16: 137-146.

Naiki, A. \& Nagamasu, H. 2004. Correlation between distyly and polyploidy level in Damnacanthus (Rubiaceae). American Journal of Botany 91: 664-671.

Naiki, A. 2012. Heterostyly and the possibility of its breaks by polyploidization. Plants Species Biology 27: 3-29

Newstron, L.E.; Frankie, G.W. \& Baker, H.G. 1994. A new classification for plant phenology based on flowering patterns in lowland tropical rain forest tress at La Selva, Costa Rica. Biotropica 26: 141-159.

Passos, L. \& Sazima, M. 1995. Reproductive biology of the distylous Mannetia luteo-rubra (Rubiaceae). Botanica Acta 108: 309-313.

Pereira, Z.V.; Vieira, M.F. \& Carvalho-Okano, R.M. 2006. Fenologia da floração, morfologia floral e sistema de incompatibilidade em espécies distílicas de Rubiaceae em fragmento florestal do Sudeste brasileiro. Revista Brasileira de Botânica 29: 471-480.

Pleasants, J.M. 1980. Competition for Bumblebee Pollinators in Rocky Mountain Plant Communities. Ecology 61(6): 1446-1459.

Proctor, M.; Yeo, P. \& Lack, A. 1996. The natural history of pollination. Harper Collins Publishers, London.

Richards, A.J. 1986. Plant Breeding systems. London, Allen \& Unwin.

Richards, J.H. \& Koptur, S. 1993. Floral Variation and distyly in Guettarda scabra (Rubiaceae). American Journal of Botany 80: 31-40
Rossi, A.A.B.; Oliveira, L.O. \& Vieira, M.F. 2005. Distyly and variation in floral traits in natural populations of Psychotria ipecacuanha (Brot.) Stokes (Rubiaceae). Revista Brasileira de Botânica 28: 285-294.

Ruiz, T.Z. \& Arroyo, M.T.K. 1978. Plant reproductive ecology of a secondary deciduous tropical forest. Biotropica 10: 221-230.

Sakai, S. \& Wright, S.J. 2008. Reproductive ecology of 21 coexisting Psychotria species (Rubiaceae): heterostyly lost? Biological Journal of the Linnean Society 93: 125-134.

Sarmiento, G. \& Monasterio, M. 1983. Life forms and phenology. In: Bouliere, F. (Ed.) Ecosystems of the word: tropical savannas. Amsterdam: Elsevier. p. 79-108.

Schoen, D.J; Morgan, M.T. \& Bataillon, T. 1996. How does self-pollination evolve? Inference from floral ecology and molecular genetic variation. Philosophical Transactions of the Royal Society of London, Series B 351: 1281-1290.

Sobrevila, C.; Ramirez, N. \& Enrech, N.X. 1983. Reproductive biology of Palicourea fendleri and P. petiolaris (Rubiaceae), heterostylous shrubs of a tropical cloud forest in Venezuela. Biotropica 15: 161-169.

Teixeira, L.A.G. \& Machado, I.C. 2004a. Sabicea cinerea Aubl. (Rubiaceae): distilia e polinização em um fragmento de floresta Atlântica em Pernambuco, Nordeste do Brasil. Revista Brasileira de Botânica 27: 193-204.

Teixeira, L.A.G. \& Machado, I.C. 2004b. Biologia da polinização e sistema reprodutivo de Psychotria barbiflora DC. (Rubiaceae). Acta Botanica Brasilica 18: 853-86

Toledo R.; Carvalho, A.; Hashimoto, D.; Rodrigues, M.; Ferreguti, R.; Consolaro, H.; Hay, J. \& Oliveira, P.E. 2007. Caracterização Morfológica de Quatro Espécies de Palicourea Aubl. (Rubiaceae) do Cerrado do Brasil Central. Revista Brasileira de Biociências 5: 732-734

Virillo, C.B.; Ramos, F.N.R.; Castro, C.C. \& Semir, J. 2007. Floral biology and breeding system of Psychotria tenuinervis Muell. Arg. (Rubiaceae) in the Atlantic rain forest, SE Brazil. Acta Botanica Brasilica 21: 879-884

Weems, H.V.J. 1953. Notes on collecting syrphid flies (Diptera: Syrphidae). The Florida Entomologist 36(3): 91-98. 